\title{
Entrepreneurial Motives in Two Emerging Economies: A Comparison between Urban Mexico and Morocco
}

Yves Robichaud

Professor, Department of Accounting, Laurentian University, Canada

Jean-Charles Cachon

Professor, Department of Marketing and Management, Laurentian University, Canada

Abdellatif Taghzouti

Professor, École nationale de Commerce et de Gestion, Université Sidi Mohamed Ben Abdella, Morocco

\author{
Abdelouahid Assaidi \\ Professor, Department of Finance and Operations, \\ Laurentian University, Canada \\ José Nicolas Barragan Codina \\ Professor, Faculty of Accounting and Management, \\ Universidad de Nuevo Leon, Mexico
}

Doi: $10.2478 / \mathrm{mjss}-2019-0014$

\section{Abstract}

This research tried to identify similarities and differences in motives between male urban entrepreneurs from Mexico and Morocco. The Mexican sample of 192 respondents was drawn from Chambers of Commerce listings in Guadalajara and Monterrey. The Moroccan sample of 222 respondents came from the Fès-Meknès region. In both countries a majority of entrepreneurs went into business by necessity and pursued monetary goals in order to secure their financial future for their families and for themselves. Larger cohorts of younger entrepreneurs were present in Mexico, where female spouses tended to be more often involved in their husband's business and contributing more to family income, as compared to Morocco. In Mexico, a larger proportion of entrepreneurs were also expressing a very strong interest for intrinsic goals involving self-actualization, meeting challenges, while Moroccan respondents were more in search for autonomy and independence besides pursuing extrinsic or financial goals. Results generally confirm results obtained elsewhere in Africa and Latin America.

Keywords: Entrepreneurship; Entrepreneurial Motives; Necessity Entrepreneurs; Mexico; Morocco

\section{Introduction}

It is important to highlight the similarity of the geopolitical situations of Mexico and Morocco with respect to their main commercial partners. Both Southern countries have, in the past, controlled 
significant territories located within current Northern trading partners: for Mexico, in the United States (Texas and the South-West, including the states of California, Arizona, Nevada, Utah, New Mexico and Colorado, Allen, 1967) and within the European Union for Morocco (territories of the former Almoravid then Almohad dynasties between 1070 and 1269, covering up to half of the Iberian Peninsula, Lévi-Provençal 1928, Buresi 2008). Both countries had established formal economic agreements with their Northern trade partners by the end of the twentieth century, as well as treaties regarding foreign direct investments and immigration. For example, both countries have significant numbers of expatriates working in Northern countries, while contributing to their home country economy by transferring funds to relatives. Both Morocco and Mexico also developed sizable tourism sectors with a predominance of clients coming from their respective Northern economic partner countries.

With respect to small and medium-sized firms (SMEs), their importance in the global economy has been established, and both Mexico and Morocco display similar situations. In 2017, Mexico had a total of about four million firms, of which $99.8 \%$ were SMEs. $57.2 \%$ of these SMEs belonged to the informal economy (STPS-INEGI, 2017). Mexican SMEs generated $52 \%$ of the gross domestic product (GDP) and $72 \%$ of employment (Federal Government of Mexico, 2016). Ranked as the twelft economy in the world in 2015, with a GDP of USD 1064 billion, 80\% of Mexico's exports went to Canada and the United States (CIA World Fact Book, 2016).

In Morocco, SMEs represent $93 \%$ of the total number of firms, $46 \%$ of total employment, $33 \%$ of total investments, and $38 \%$ of national production. $75 \%$ of the 500000 Moroccan SMEs are estimated to be part of the informal economy (African Development Bank, 2009), and only $8 \%$ of all formal sector firms are owned by women in Morocco, as compared to $15 \%$ in Algeria and $24 \%$ in Egypt (Esfahani and Bahramitash, 2015). Morocco's USD 107 billion GDP ranked third in North Africa and fifth in Africa in 2014, with a growth of $2.7 \%$ that year. The African Development Bank estimated growth to be 4.5\% and 5\% in 2015 and 2016 (African Development Bank, 2015).

This research had three purposes: 1) To determine the motives expressed by Mexican and Moroccan entrepreneurs, 2) To identify the orientation and possible differences of entrepreneurial motives between Mexico and Morocco, and 3) To verify whether factorial analyses would yield variable groupings similar to those observed in the literature among other similar economies.

The study of entrepreneurial motivations is grounded in theoretical models of performance analysis (Morris et al., 2006; Blawatt, 1995; Naffziger et al. 1994; Herron and Robinson, 1993) highlighting the importance of entrepreneurial goals with respect to business growth. The attention given to motivation variables by these scholars is based on the premise that a better understanding of entrepreneurial motives would contribute to a better understanding of the behaviors chosen by entrepreneurs and provide more detailed explanations about the impact of these behaviors on business performance.

Four main reasons justified the present study: 1) There are very few empirical studies about entrepreneurship in Morocco and Mexico (Foster et Howard, 2006; Cachon et al., 2013); 2) Both countries have strong economic and trade relations with developed regions, i.e. NAFTA (North American Free Trade Agreement) countries for Mexico, and the European Union for Morocco; 3) SMEs represent an important share of the economy of these two countries in terms of sources of employment and GDP share, and 4) While Mexico tries to diversify its exports in light of the 20172018 NAFTA renegociation (which will reduce exports to the U.S.), Morocco tries increasing exports to maximize the advantages provided by the economic partnership agreement signed in 1996 with the European Union.

These reasons justify the importance of understanding how SMEs are created and grow, in order to facilitate the economic development of both countries. This research identified and analyzed the entrepreneurial motives of $\mathbf{4 1 4}$ male entrepreneurs from Mexico and Morocco. Data were collected through a questionnaire already used for other international surveys in the United States, France, Canada and several African countries.

This article comprises three parts: the first part presents the current situation of entrepreneurship in Mexico and Morocco; the second part provides a literature review of entrepreneurial motives in both countries, while the last section includes the methodology, the results, and the conclusions of the present research. 


\section{Literature Review}

\subsection{Entrepreneurship in Mexico}

Based on Porter, Sachs and McArthur (2002) typology, the World Economic Forum classifies national economies in three categories, i.e. 1) Factor-driven economies based on adequate infrastructures and other basic economic requirements, 2) Efficiency-driven economies able to develop their market base and compete through higher education and efficiencies in technology and in labor, capital and goods and services markets, and 3) Innovation-driven economies able to compete through both innovation and business dynamism (Schwab, 2016). Countries with higher business dynamism have, according to Schwab (2016), economic conditions that allow new businesses to start more rapidly, at a lower cost, where attitudes towards financial risk are positive, and where new, innovative firms can grow more rapidly.

According to the Global competitiveness index of 2016-17 (Schwab, 2016) and 2017-18 (Schwab, 2017), Mexico advanced from the $57^{\text {th }}$ to the $51^{\text {st }}$ rank on a total of 138 countries in 201617 , and remained at that rank in 2017-18. While corruption, crime, and inefficient bureaucracy were cited as the most problematic factors for doing business in Mexico, the quality of public health, government and policy stability, low inflation, a strong work ethic, an easier access to capital funding, and a capacity for innovation were cited as positive business factors (Schwab, 2017).

On a global scale, Mexico ranks high in terms of total entrepreneurial activity (TEA index), with a rate of 25\% in 2015 (Kelley, Singer and Herrington, 2016). Moreover, in Mexico the younger generation is very entrepreneurial: the 16 to 24 age group represents almost $30 \%$ of the total number of entrepreneurs, whose average age is 33.5 (Bosma et al., 2007). Mexico has been very dynamic in terms of business creation. The 2004 and 2009 economic censuses showed a $21.1 \%$ increase in the number of economic units, and an increase of $19.6 \%$ in employment (INEGI, 2009). Policies implemented in Mexico over the last decades have been credited for being behind this economic growth, including a disengagement of the state from the economy, progress towards more competition, as well as free trade with the U.S. and Canada (Méndez, 1998). It is notable that over $75 \%$ of Mexican imports involve semi-finished products destined to manufacturing (Sánchez et al., 2014).

Furthermore, Mexico has, over the recent years, increased its focus on entrepreneurship. In 2012, a start-up fund for co-investments in new firms was created by the federal government through the federal development bank, the Nacional Financiera (NAFIN): this was a first in Mexico (North, 2012). In addition, in early 2013 the government created the National Institute of the Entrepreneur (INADEM), an administrative entity integrated into the Ministry of the Economy, with a mandate to develop a stronger entrepreneurial ecosystem (INADEM). A support network of over 500 incubator programs available in 190 cities exists across Mexico, including 50 incubators dedicated to high growth potential start-ups (New Venturist). Such actions underscore the commitment of the government to improve Mexico's potential for innovation and competitiveness despite enduring difficulties to mobilize venture capital.

To bolster these efforts, Mexico's geographic proximity to the U.S. combined with its participation to NAFTA, as well as to twelve other free-trade agreements involving 44 countries offer enormous opportunities to exporters (Villarreal, 2017). Increased labour costs in China also drove relocations back to Mexico from manufacturers supplying U.S. clients. Over the recent years, Mexico has progressed considerably since the federal government identified entrepreneurship as a vector of economic growth.

Some structural weaknesses still hamper Mexico's entrepreneurial drive, notably a limited access to short and long-term financing which limits firms' growth capacity, and a low level of postsecondary education which reduces the supply of qualified personnel. In the medium term, this could seriously limit Mexico's contribution to the knowledge based economy (EY, 2013). Mexico's economy has also been directly hit by the oil prices collapse since 2014 , by a sluggish world trade, by a reduced industrial output after 2009 , before being hit by the adverse effects of the Trump administrations announcements regarding the Transpacific Partnership, NAFTA, and the erection of a wall between the U.S. and Mexico (Villareal, 2017, 16). Despite the above, Mexico remains one of 
the most competititive economies in the region and keeps forging ahead in terms of the fundamental factors necessary to its future prosperity.

\subsection{Entrepreneurship in Morocco}

Morocco is part of the MENA region (Middle East and North Africa), also labeled as Western Asia (United Nations, 2018), a group of 18 Arab countries which also includes Bahrain, Egypt, Iraq, Jordan, Kuwait, Lebanon, Libya, Mauritania, Oman, Palestine, Qatar, Saudi Arabia, the Sudan, the Syrian Arab Republic, Tunisia, the United Arab Emirates and Yemen. While a majority of these countries are oil producers, investors in the region have changed their behavior by investing less in oil and gas and more into consumer related companies and services, following oil prices decline and volatility. This has resulted in a tendency to economic diversification among these countries (GIH, 2008; MENAPEA, 2015).

According to a 2015 survey "Entrepreneurship in the Middle East ", 64\% of working age respondents would rather own their own firm instead of being employed. Baschiera (2018) reported that MENA entrepreneurs tended to see their business as a long term involvement, with $56 \%$ intending to keep their business at least 15 years, by opposition to only $26 \%$ of Asians, $30 \%$ of Europeans and $42 \%$ of U.S. respondents. Self-employment has grown in importance over the recent years following economic and political turbulence, a lack of employment, oil price fluctuations, as well as a growing desire to be economically independent among the younger generations.

According to the World Economic Forum's Global competitiveness index of 2016-17 (Schwab, 2016) and 2017-18 (Schwab, 2017), Morocco moved down from the $70^{\text {th }}$ to the $71^{\text {st }}$ rank among 138 countries. Compared to other economies with a similar development level, Morocco remains one of the least entrepreneurial economies (GEM, 2017).

An acceleration of the creation of businesses out of opportunity situations is, however, noticeable, by opposition to businesses created in reaction to lack of employment. In 2016, the Entrepreneurial Activity Index grew from $4.4 \%$ to $5.6 \%$ of the total workforce, of which only $1.2 \%$ represents necessity entrepreneurship (GEM, 2016). This development has been explained by an increased rate of business creations from $4.3 \%$ in 2016 compared to $3.2 \%$ in 2015 . However most of the new Moroccan firms only imitate existing technologies and activities in highly competitive sectors. This results in a quasi absence of innovation and limited job creation. According to GEM $(2016,2017)$, there are regional differences in Morocco in terms of entrepreneurial activity. Southern regions tend to be less entrepreneurial as compared to Northern regions. In 2017, Casablanca-Settat in the North had the highest rate of business creation in Morocco, at $6.5 \%(8.5 \%$ in 2016).

Most of the necessary components for a healthy entrepreneurial environment are present in Morocco, but a major hindrance is the lack of communication between the government and the private sector. As a result, growth happens haphazardly in the midst of a lack of support for entrepreneurial activities (World Bank, 2017). The World Bank has observed the presence of some start-up support; however it requires fitting better the existing entrepreneurial fabric and must be bolstered by infrastructure quality improvements. Moreover, the current Moroccan skills deficit prevents companies from reaching their full potential. While being generally highly technically qualified, entrepreneurs lack the business skills required to bring their product concepts to market. A lack of mentorship further limits entrepreneurial growth, as mentors able to guide entrepreneurs through all the steps towards growth are hard to find. Due to the lack of a tradition of « giving back " to one's community, many experienced entrepreneurs have no desire to help their younger counterparts (World Bank, 2017).

Institutional measures aimed at remeding this situation have been adopted. In 2016, the European Investment Bank (EIB) and the World Bank Group (WBG) signed a joint initiative called Boost MENA, supporting nascent entrepreneurs, young people and women in particular (World Bank, 2016). Boost MENA combines investment capital financing for both innovative startups and existing early-stage growth firms with the backing of significant technical assistance. The integrated approach chosen by EIB and WBG is supposed to support at the same time the early stages of 
business creation as well as the risky subsequent steps. The project was also designed to provide long-term entrepreneurial support, including the following: business incubators/accelerators, seed funding and access to business angels, networking, crowdfunding platforms, venture capital and social impact funds.

The main barriers to business startup in Morocco are, in declining order, the lack of access to financing, the shortage of skilled labor, government bureaucracy, tax levels, an insufficient capacity to innovate, corruption, fiscal rules, the lack of infrastructures and the poor work ethic among the workforce (WEF, 2017).

\subsection{Motivations of Mexican and Moroccan entrepreneurs}

Starting one's own firm is highly risky. Understanding the motives behind the choice made by a person to go down such a path is a recurring topic in entrepreneurship research (Zimmerman and Chu, 2013). In fact, the understanding of the entrepreneurial process results from the discovery of the reasons to start and grow a company (Kuratko, Hornsby and Naffziger, 1997), while motivation represents the link between entrepreneurial intentions and actions (Carsrud and Brannback, 2011). According to scholars, several factors interact when an individual decides to become an entrepreneur: personal characteristics and environment, industry-specific environment, personal goals, a viable project and perception of success probabilities, and personal expectations (Cohen and Bacdayan, 1994). The motives for creating one's own enterprise can be understood as a personal process of becoming resulting from the combination of several contributing factors. This motivation should be interpreted as the expression of a personal attitude resulting from an individual's self-image and one's needs for achievement, autonomy, creativity, control, as well as one's attitude towards risk-taking at a moderate level (Cromie, 2000).

Scholars generally agree on the presence of two main categories of factors related to the choice of an entrepreneurial activity: 1) «Pull » factors relate business creation to opportunities seized following deliberate choices from the entrepreneur 2) «Push " factors describe realities where a person is forced into business by circumstances (Fairlie, 1996). " Pull » factors have been associated to the positive aspects of self-employment, presented as an attractive activity to which a person is deliberatly dedicated (Fairlie and Meyer, 1991). Motives most often cited to refer to this category comprise the needs for independence and autonomy, self-accomplishment, achievement, and the possibility of more important financial gains. "Push " motives correspond to negative events forcing an individual to start in business, where self-employment is perceived as a last recourse resulting from an exclusion from the labor market (Feldman, Koberg and Dean, 1991). Chronic unemployment, low wages, and discrimination have been cited as causes of such an exclusion (Light, 1979), as well as lay-offs, underemployment, dissatisfaction with previous jobs, health issues, family financial issues, a need for flexibility due to family responsibilities (i.e. taking care of children as well as older parents), or the death of a family business co-owner (Chedli, 2016).

The extant literature also highlighted a wide-ranging diversity of economic motives among entrepreneurs, such as financial remuneration and company equity-building (Langan-Fox and Roth, 1995), generating post-retirement extra income (Aspaas, 2004), acquiring personal assets, and increasing personal income (Kuratko et al., 1997). As per non-economic motives, they would include employment security for the entrepreneur and family (Aronoff and Ward, 1995), selfaccomplishment, the opportunity to create something (Aspaas, 2004), independence and autonomy, being in control by being one's own boss, personal growth, gaining public recognition, meeting a challenge, or satisfying a need for success (Kuratko et al., 1997; Robichaud, McGraw and Roger, 2001).

This emphasis on the role of entrepreneurial goals has led scholars to develop instruments in order to measure entrepreneurial motives. In North America, research conducted by Kuratko, Hornsby and Naffziger (1997) provided a 15-item instrument, while Robichaud et al., (2001) validated an 18-item questionnaire. In both cases, factor analyses identified four categories of motivational factors among samples of entrepreneurs: extrinsic motives, intrinsic motives, family reasons, and the need for autonomy/independence. Further research (Benzing, Chu and Kara, 
2009; Robichaud, Cachon and Haq, 2010; Larsson and Erlandsson, 2010; Zimmerman and Chu, 2013; Fatoki, 2014; Hassan, Ramli and Desa, 2014) found the same groupings as Kuratko et al. (1997) and Robichaud et al. (2001).

\subsubsection{Motivations of Mexican entrepreneurs}

Survey-based field studies on entrepreneurial motives in Mexico and elsewhere in Latin America are uncommon. Samaniego (1998) distinguished self-employed workers from entrepreneurs with employees and found motivational differences between these two categories. Among business founders having employees, $40 \%$ declared an unsatisfactory remuneration as their main entrepreneurial motive, $25 \%$ chose as a second motive the closing of their employer or the end of a contract. Other reasons were related to more flexibility in a managerial position, shorter working hours, proximity from the residence, and other reasons. Conversely, $33 \%$ of those who became self-employed without having employees mentioned an involuntary end of employment as the main motive for their decision. An insufficient salary and a need for flexibility were, in order, the next two motives.

Samaniego's results (1998) correspond to those obtained more recently by Radojevich-Kelley (2014), where $64 \%$ of the Mexican entrepreneurs surveyed had rated financial independence as their primary motive for having started a business. To realize their dream and personal independence were respectively mentioned by $18.7 \%$ and $17.2 \%$ of the respondents. Over $57.5 \%$ of them considered financial prosperity as the main reward for an entrepreneur, with a higher income, the possibility to sustain their family and to enjoy a certain financial and economic freedom. Autonomy and independence ranked second (33.6\%), providing the latitude to choose your own work hours and not having a boss telling you what to do.

Kantis, Ishida and Komori (2002) also identified the desire to be one's own boss as a most important motivation factor. In fact, $80.5 \%$ of Mexican entrepreneurs declared having been motivated by a desire for autonomy and independence.

\subsubsection{Motivations of Moroccan entrepreneurs}

Biygautane (2015) noted that several Arabo-Persian Gulf countries faced the dual challenge of creating youth employment while developing economic action beyond the oil sector. For Le Cabellec (2017), Morocco's long term growth depends in part on the ability of the country to foster a small business economic fabric able to buttress the emerging industrial sector.

There is a belief that, in emerging economies, entrepreneurship is mainly resulting from the necessity for individuals to increase or stabilize their income and their professional activities. Benzing and Chu (2009) have reported such situations in Nigeria, Ghana, and Kenya. Bewayo (1995), in Uganda, noted that $61 \%$ of the local entrepreneurs were motivated by monetary gain but were at the same time more interested in owning a business rather than depending on a salary due to the freedom and independence they could enjoy.

It is also a fact that, with about one-third unemployment among the youth, the MENA region has among the highest unemployment rates in the world. A 2014 survey by Bayt across the MENA regions revealed that, for $78 \%$ of the respondents, financial stability and independence were the first priority in life. While $66 \%$ desired to learn and explore new opportunities, $57 \%$ wished to devote more time to their family. The rising cost of living and a lack of financial stability were the top two causes of stress for working respondents (Bayt, 2014).

In Morocco, Gray, Foster and Howard (2006) surveyed 201 entrepreneurs, mainly in the Casablanca area, from a wide range of industries. While approximately two-thirds of the respondents had become entrepreneurs by opportunity (pull factors), the others had been forced into self-employment by various circumstances (push factors). Both psychological and situational factors were described to be involved. In terms of their attitudes, Moroccan entrepreneurs displayed a strong desire for achievement associated with a strong commitment to problem-solving and goal attainment, including overcoming competitors. These entrepreneurs were also motivated by a strong need for independence, expressed as a desire to be their own boss. At the same time, they 
also yearned for a better life style for themselves and their family through financial autonomy. However, except for a few younger ones, they were adverse to change and therefore not leaning towards any innovation. A large proportion of them were involved in a family business or in established industries offering staple products or services in highly competitive markets.

Situational factors comprise several aspects of the economic environment that entice Moroccans towards entrepreneurship, in particular the increasing competition for obtaining employment, and government actions encouraging foreign trade, job creation, and measures aimed at increasing per capita income. Gray et al. (2006) found a majority of respondents pulled towards entrepreneurship by opportunities stemming from their past experiences, into which they invested all their efforts. Conversely, those respondents who were forced into an entrepreneurial career had been either dissatisfied with a previous employed experience, or had decided to try something else by showing to others what they could accomplish by themselves. These results have recently been corroborated by Yatribi and Balhadj (2016) in a study among Moroccan engineers, describing how job dissatisfaction was the dominant motive for them to resign before starting up their own firm. Such dissatisfaction results primarily from a lack of challenge within the tasks required from them, a situation where they feel devalued, with their self-esteem being eroded as a result. They are often confronted with autocratic forms of management within which they develop a sense of powerlessness, stemming from being barred from participating into decision-making, from innovating, and from contributing to the improvement of the task-related modes and processes. Such dissatisfaction is exacerbated by ancient practices including favoritism, a disrespect of the individual, ceilinged career paths, and even invoking religion as an excuse for blocking any change.

Yatribi and Balhadj (2016) highlighted seven motivation factors related to entrepreneurship, the dominant one being a quest for autonomy resulting from a desire for independence. The ultimate goals of this process appeared to be multiple: for some, it was a way to apply their personal work ethics, for others having one's own firm meant an access to self-actualization, to higher self-esteem, and even more flexible working schedules.

Gray et al. (2006) also found that over half of the respondents came from families where one of the parents was already in business, thus acting as role model. Others were guided into business by other relatives or friends, whereas less than $30 \%$ said they did not follow any model. Role models often act as mentors both at the startup stage and in the following years. For Yatribi and Balhadj (2016), several entrepreneurs recognized how being acquainted with colleagues and friends who became entrepreneurs before them convinced them to walk down a similar career path.

\section{Methodology}

\subsection{SMEs defined}

There is no universal definition of SMEs in the literature. For the purpose of this research, the Organization for Economic Co-operation and Development (OECD) definition has been used, describing an SME as a firm with less than 250 employees.

\subsection{Sampling and data collection}

\subsubsection{Morocco: Fès-Meknès region - Mexico: Guadalajara and Monterrey}

Data used to identify potential respondent firms were obtained from chambers of commerce in both Mexico and Morocco. In Fès-Meknès, the 222 respondents were contacted by master's students as part of their internship activities within the firms. Such work placements are part of the final Master level year with École Nationale de Commerce et de Gestion de Fès (ENCG-Fès National School of Commerce and Management). Each student had committed to administer between one and three questionnaires, depending on the number of co-owners within the firm. 110 students were involved. Each questionnaire required to be stamped by the firm's owners in order to ensure the accuracy and the veracity of the responses.

In Mexico, all legally constituted firms have the obligation to register into their local chamber of 
commerce. The 278 respondents (of which 192 males) were visited in person as well by graduate students from the Business Schools at the Universidad Panamericana in Guadalajara and at the University of Nuevo León in Monterrey. Students were under the supervision of local scholars.

\subsubsection{Mexico: Guadalajara, Monterrey and the states of Jalisco and Nuevo Leon}

Mexican authorities monitor the relative importance of the informal economy in every state as well as nationally. The International Labor Organization (ILO) defined the informal economy based on Hussmanns' (2004) definition of informal employment, as representing non-criminal informal economic activities, a concept applied and measured in Mexico by Negrete (2008). These activities are classified under two category groups: the economic unit (household employing domestic workers, subsistence agriculture, non-agricultural informal sector, non-profit sector, and formally established firms) and the employment status (employers, independent workers, formal and informal employees).

The cities selected for this study, Guadalajara (Jalisco state) and Monterrey (Nuevo León state) are respectively the second and third of Mexico in terms of population. Monterrey and its region had a 4.1 million population in 2015 , or $80 \%$ of the Nuevo León total. According to STPS (2016 and 2017), in 2017 the workforce equaled 2.45 million, as compared to 2.3 million in 2015, with a participation rate of $63.7 \%$ (up from $61.2 \%$ in 2015 ). Unemployment fell from $4.9 \%$ in 2015 to $4 \%$ in 2017.

The state of Nuevo León is one of Mexico's most economically active, where 156,000 SMEs employ $76 \%$ of the workforce. With only $4 \%$ of Mexico's total population, Nuevo León produced respectively $7.1 \%$ and $7.5 \%$ of the national GDP in 2010 and 2014 (INEGI, 2014 and 2016), and $11 \%$ of the manufacturing output (INEGI, 2016b). The state generated $11 \%$ of total exports and received $10 \%$ of Mexico's foreign direct investments (FDI) from the U.S., Europe, and Asia, while creating $9 \%$ of total formal jobs. Manufactured products exports increased from USD 17.3 billion to USD 31.5 billion from 2009 to 2014 (INEGI 2016), and the Nuevo León's annual income per capita is almost double the national average (Nuevo León 2013).

In 2017, Nuevo León's informal economy represented $36 \%$ of the total, the lowest proportion in Mexico, with Chihuahua state; in Jalisco state, the informal economy rate was $49.9 \%$ in 2017 (STPS-INEGI, 2017), as compared to a $57.2 \%$ national average proportion of informal activity. Economic growth was measured at $6.2 \%$ for 2015.

Guadalajara's region had over 5 million in population in 2017 (IIEG, 2017) and a participation rate of $57.9 \%$. Associated to mariachis music and tequila production, Guadalajara is also a Mexican Silicon Valley and a major wholesale hub (Webber, 2015). Third industrial region of Mexico (after Mexico City and Monterrey) it produces $37 \%$ of Jalisco state's GDP. According to INEGI (2016c), companies had an average lifespan of 7.5 years in Jalisco, and 6.9 years in Nuevo León states in 2015.

USD 1.2 billion or 5.4\% of Mexico's total direct investments were spent in Jalisco in 2014 (Mundo Ejecutivo, 2015). Jalisco also has the highest proportion of self-employed in the country, with 11 registered formal firms for one thousand residents, as compared to 10 in Mexico City, and 6 in Nuevo León (Informador, 2015). Most of the 90,000 firms in Guadalajara are SMEs (INEGI 2014b). Pineda (2014) underscored the importance of female entrepreneurs in Guadalajara, particularly in retail, as well as the city leadership's support for them.

\subsubsection{Morocco - The Fès-Meknès region}

Second largest city in Morocco with a population of over 1.1 million, the city of Fès is located 180 $\mathrm{km}$ east of Rabat, the capital city. Considered as the cultural and spiritual metropolis of Morocco, Fès harbors Al Quaraouiyine University, founded in 859, and recognized by UNESCO as the oldest operating educational institution in the world.

The Fès-Meknès region had a 4.2 million population in 2014 (HCP, 2016). Saad Alami (2016) indicated that $61 \%$ of the region's firms were located in Fès, while the regional economy accounted for $9.2 \%$ of Morocco's GDP (Haddad, 2017) and 2.4\% of exports. The Agri-Food, Textile, and 
Leather Goods industries accounted for $60 \%$ of the local output. While the local agricultural output represented $21.7 \%$ of the national production in that sector, the share of the food industry was $9.9 \%$, and the textile and leather industries combined accounted for $11.3 \%$ of the total national production (Haddad, 2017).

In addition, Haddad, El-Hattab and Ait-Ali (2017) showed that the Fès-Meknès region had $12.5 \%$ of its economy producing for exports, $51 \%$ for local demand, and the remaining $36.5 \%$ destined to other regions in Morocco. The most important client regions of Fès-Meknès were Grand Casablanca $(9.4 \%$ of the total Fès-Meknès production), Rabat $(6.1 \%)$ and Tangiers $(5.0 \%)$. Demand from other regions represented less than $5 \%$ per region.

Since 2016, the Fès Shore digital park attracts firms specialized in offshoring services in the knowledge economy. Tourism is another growth sector in the region, as well as communications with the development of over 25 call centers in 2016 (Saad Alami, 2016).

\subsection{Variables measurement}

Data were collected through a survey questionnaire based on instruments developed and validated by Robichaud, McGraw and Roger (2001) and Robichaud (2011). These instruments were developed on the basis of a literature review identifying the major motives categories present in the extant literature. Motivational constructs were then validated among samples of entrepreneurs and through further research in various countries, including Canada (Robichaud et al., 2010), Mexico and the U.S. (Cachon et al., 2013) and France (Assaidi, Kizaba and Guilluy-Sulikashvili (2015). For the purpose of this study, entrepreneurial motives were measured with an 18-statement Likert-type scale ranging from $1=$ unimportant to $5=$ extremely important.

\subsection{Data analyses}

Data were analyzed with the SPSS package, using the following statistics: Mann-Whitney non parametric tests; T-tests of differences between means; principal components analyses, generally referred to as factor analyses (with orthogonal rotation in varimax mode); descriptive statistics such as means and standard-deviations.

\section{Results}

\subsection{Respondents' profile}

Table 1 summarizes descriptive statistics of the personal and organizational characteristics relevant to respondents by country. Age distributions are significantly different, where young (20 to 29 years of age) entrepreneurs represented $21 \%$ of the total Mexican sample (only $5 \%$ for Morocco). Conversely, respondents over 29 years of age formed $95 \%$ of the sample from Morocco, and $79 \%$ of the sample from Mexico. Moroccan entrepreneurs had a significantly higher education level than Mexicans, as $84 \%$ of them had a postsecondary degree, as compared to $76 \%$ for Mexicans. Also, Moroccans had significantly more previous management experience, as $50 \%$ of them had at least six years of experience, while $33 \%$ of the Mexicans did; however, there was no significant difference in terms of previous experience in their current industry.

Respondents from both countries shared a number of working characteristics. They worked for similar hours each week $(50 \%$ of the Mexicans and $57 \%$ of the Moroccans worked more than 41 hours per week); a majority was their firm's founders (85\% in Mexico and $80 \%$ in Morocco) and many became entrepreneurs by necessity (50\% of the Mexicans and $56 \%$ of the Moroccans). Personal differences were observed in terms of marital status, where Moroccans were more often married or living with a spouse $(86 \%)$ than Mexicans $(72 \%)$, however, spousal contributions to family income were significantly higher in Mexico: $53 \%$ of Mexican entrepreneurs' spouses contributed to family income, while $38 \%$ of the Moroccan respondents were in that situation. Finally, spouses were involved in the business in $36 \%$ of the cases in Mexico as compared to only $14 \%$ in Morocco. All respondents were male in both countries. 
Table 1: Respondents' profile by country (Morocco: $n=222$, Mexico: $n=192$ )

\begin{tabular}{|c|c|c|c|c|c|}
\hline \multicolumn{3}{|l|}{ Personal Characteristics } & \multicolumn{3}{|l|}{ Organizational Characteristics } \\
\hline & $\begin{array}{c}\text { Mexico } \\
\%\end{array}$ & \begin{tabular}{|c|} 
Morocco \\
$\%$
\end{tabular} & & \begin{tabular}{|c|} 
Mexico \\
$\%$ \\
\end{tabular} & \begin{tabular}{|c|} 
Morocco \\
$\%$
\end{tabular} \\
\hline $\begin{array}{l}\text { Age } \\
20 \text { to } 29 \text { years } \\
30 \text { to } 49 \text { years } \\
50+\end{array}$ & $\begin{array}{l}21 \\
49 \\
30\end{array}$ & $\begin{array}{c}5 \\
57 \\
38\end{array}$ & $\begin{array}{l}\text { Business success } \\
\text { None/ minor profitability } \\
\text { Average profitability } \\
\text { Highly profitable }\end{array}$ & $\begin{array}{c}7 \\
43 \\
50\end{array}$ & $\begin{array}{c}1 \\
41 \\
58\end{array}$ \\
\hline $\begin{array}{l}\text { Education* } \\
\text { High School } \\
\text { College/university degree }\end{array}$ & $\begin{array}{l}24 \\
76\end{array}$ & $\begin{array}{l}16 \\
84\end{array}$ & \begin{tabular}{|l|} 
Number of employees \\
$1-5$ employees \\
$6-10$ employees \\
11 employees and + \\
\end{tabular} & $\begin{array}{l}57 \\
14 \\
29 \\
\end{array}$ & $\begin{array}{l}48 \\
22 \\
30 \\
\end{array}$ \\
\hline $\begin{array}{l}\text { Married or Common Law } \\
\text { Spouse involved in business } \\
\text { Business started due to economic necessity }\end{array}$ & $\begin{array}{l}72 \\
36 \\
50 \\
\end{array}$ & $\begin{array}{l}86 \\
14 \\
56\end{array}$ & $\begin{array}{l}\text { Industry/Economic Sector } \\
\text { Retail } \\
\text { Services } \\
\text { Manufacturing }\end{array}$ & $\begin{array}{l}41 \\
48 \\
11\end{array}$ & $\begin{array}{l}36 \\
46 \\
18\end{array}$ \\
\hline $\begin{array}{l}\text { Previous Experience in Current Industry } \\
\text { None } \\
1-5 \text { years } \\
6-10 \text { years } \\
11 \text { years + }\end{array}$ & $\begin{array}{l}22 \\
40 \\
18 \\
20\end{array}$ & $\begin{array}{l}16 \\
45 \\
24 \\
15\end{array}$ & $\begin{array}{l}\text { Firm Startup* } \\
\text { Started by owner } \\
\text { Acquisition } \\
\text { Inheritance or franchise }\end{array}$ & $\begin{array}{l}85 \\
12 \\
3\end{array}$ & $\begin{array}{c}80 \\
5 \\
15\end{array}$ \\
\hline $\begin{array}{l}\text { Previous Management Experience }{ }^{* * *} \\
\text { None } \\
1-5 \text { years } \\
6-10 \text { years } \\
11 \text { years }+\end{array}$ & $\begin{array}{l}25 \\
42 \\
19 \\
14\end{array}$ & $\begin{array}{l}13 \\
37 \\
30 \\
20\end{array}$ & $\begin{array}{l}\text { Age of the firm* } \\
1-5 \text { years } \\
6-10 \text { years } \\
11-20 \text { years } \\
21 \text { years }+\end{array}$ & $\begin{array}{l}36 \\
25 \\
26 \\
13\end{array}$ & $\begin{array}{l}26 \\
28 \\
23 \\
23\end{array}$ \\
\hline $\begin{array}{l}\text { Spousal Contribution to Family Income* } \\
\text { None } \\
1 \%-25 \% \\
26 \%-60 \% \\
61 \%-100 \%\end{array}$ & $\begin{array}{c}47 \\
29 \\
23 \\
1\end{array}$ & $\begin{array}{c}62 \\
17 \\
20 \\
1\end{array}$ & $\begin{array}{l}\text { Number of co-owners /Partners } \\
1 \text { (sole proprietorship) } \\
2 \\
3+\end{array}$ & $\begin{array}{l}45 \\
37 \\
18\end{array}$ & $\begin{array}{l}42 \\
29 \\
29\end{array}$ \\
\hline $\begin{array}{l}\text { Weekly hours worked } \\
0-20 \text { hours } \\
21-40 \text { hours } \\
41-55 \text { hours } \\
56 \text { hours }+ \\
\end{array}$ & $\begin{array}{l}24 \\
26 \\
24 \\
26\end{array}$ & $\begin{array}{c}7 \\
36 \\
44 \\
13\end{array}$ & $\begin{array}{l}\text { Debt level perception* } \\
\text { Unimportant or not very important } \\
\text { Moderately important } \\
\text { Very or extremely important }\end{array}$ & $\begin{array}{l}46 \\
27 \\
27\end{array}$ & $\begin{array}{l}28 \\
46 \\
26\end{array}$ \\
\hline
\end{tabular}

${ }^{*}: p<0.05 ;{ }^{* *}: p<0.01 ;{ }^{* * *} p<0.001$ (t-tests on continuous variables and non parametric Mann-Whitney tests on discrete variables)

Regarding organizational characteristics, table 1 reveals a similar subjective evaluation of the firm's success in both countries. For example, $50 \%$ of the respondents described their firm as highly profitable in Mexico, while $58 \%$ of the Moroccans did the same. Also similar were the distributions of the number of employees, of the firm samples by economic sector (48\% in Services in Mexico, and $46 \%$ in Morocco), as well as the number of owners or partners, most firms being owned by at least two partners in both countries. In terms of significant differences, Mexican firms tended to be more recent (36\% had under 5 years of existence, $26 \%$ in Morocco were in that category), and less in debt (46\% saw their debt level as unimportant or not very important, while only $28 \%$ were of such opinion in Morocco). 
Table 2: Distribution of responses by motivation variable - all respondents $(n=414)$

\begin{tabular}{|l|c|c|c|c|c|}
\hline Motivation variables & $\begin{array}{c}\text { Extremely } \\
\text { important } \\
\text { (\%) }\end{array}$ & $\begin{array}{c}\text { Very } \\
\text { important } \\
(\mathbf{\%})\end{array}$ & $\begin{array}{c}\text { Mildly } \\
\text { important } \\
(\%)\end{array}$ & $\begin{array}{c}\text { Not very } \\
\text { important } \\
(\%)\end{array}$ & $\begin{array}{c}\text { Unimportant } \\
\text { (\%) }\end{array}$ \\
\hline To make my own decisions & 35 & 35 & 21 & 6 & 3 \\
\hline To acquire a comfortable living & 35 & 43 & 16 & 5 & 2 \\
\hline To build up equity for retirement & 22 & 36 & 25 & 11 & 6 \\
\hline To maximize business growth & 40 & 37 & 16 & 5 & 2 \\
\hline To meet the challenge & 24 & 31 & 28 & 15 & 2 \\
\hline To prove I can succeed & 26 & 38 & 22 & 10 & 4 \\
\hline To create my own job & 40 & 37 & 14 & 6 & 3 \\
\hline To increase sales and profits & 44 & 39 & 13 & 3 & 1 \\
\hline To be my own boss & 43 & 30 & 19 & 6 & 2 \\
\hline To increase my income & 37 & 36 & 19 & 5 & 3 \\
\hline To gain public recognition & 15 & 28 & 30 & 18 & 9 \\
\hline To provide jobs for family members & 18 & 24 & 31 & 20 & 7 \\
\hline For my own satisfaction and growth & 33 & 37 & 23 & 5 & 2 \\
\hline So I will always have job security & 33 & 40 & 18 & 6 & 3 \\
\hline To build a business to pass on & 26 & 35 & 21 & 14 & 4 \\
\hline To maintain my personal freedom & 35 & 36 & 19 & 7 & 3 \\
\hline To be closer to my family & 26 & 31 & 25 & 13 & 5 \\
\hline To have fun & 23 & 30 & 19 & 15 & 13 \\
\hline
\end{tabular}

\subsection{Motivation Variables}

\subsubsection{Motivation variables scores by country and total sample}

Results from the 18-variable motivation scales distribution scores by country and total samples are presented on table 2 and table 3 . Among all 414 respondents, the highest ranking statement was « To increase sales and profits " with a total samples average score (right column in table 3 ) of 4.21 with $83 \%$ of the respondents considering it as « very important » or « extremely important ». In both countries, the score for this variable was almost identical (4.20 and 4.21). The second ranking statement was "To create my own job », with a 4.07 average score and $77 \%$ of respondents viewing it as "very important " or " extremely important ». Both statements " To maximize business growth » and « To be my own boss " arrived ex aequo in third place with a 4.06 average score, and an importance rate of respectively $77 \%$ and $73 \%$. Fourth an fifth were " To acquire a comfortable living " (average score 4.03 with $78 \%$ rating it as important), and " To increase my income " (average score 3.98 and $73 \%$ rating it as important). Extrinsic choices stand out as being preferred by respondents of both countries, forming five of the first six choices from both countries.

To the opposite, the least favored statements by respondents from both countries were, by rank order : "To gain public recognition " and "To provide jobs for family members " with average scores of respectively 3.23 and 3.25 . Only $43 \%$ of respondents with the statement « To gain public recognition», and $42 \%$ with the statement « To provide jobs for family members ", considered them from being either « very important » or « extremely important ».

In order to analyze entrepreneurial motivations in each country in further detail, table 3 presents the results of an analysis comparing the differences between mean scores for each variable. Below are the main observations deducted from table 3.

- Results from Mexico and Morocco are very similar, as four statements among the first six choices are the same, even if not ranking in the same order: "To increase sales and profits ", "To be my own boss ", " To create my own job », and " To maximize business growth ». The only differences noted among the six first choices were " To maintain my personal freedom " and " To acquire a comfortable living " selected in third and sixth ranks respectively by respondents from Morocco, and " To increase my income " and " For my own satisfaction and growth » chosen at the first and second rank by Mexican 
entrepreneurs. It is remarkable that four out of the six primary goals selected by both countries' entrepreneurs belong to the extrinsic category, as well as their respective first choice, i.e. "To increase sales and profits » for Morocco, and " To increase my income » for Mexico.

- Overall, the least important statements for all respondents were « To provide jobs for family members " and "To gain public recognition ». Examining those results by country, we find that « To provide jobs for family members " scored lowest in Morocco (3.30), while in Mexico the lowest scored statement was « To have fun » (2.77). Also notable is that, within the Moroccan sample, the statement « To meet the challenge " scored 3.33, which is statistically similar to the lowest score among that sample.

- Comparing scores from the two countries revealed interesting facts. Mexican respondents significantly $(p<0.001)$ favored the three following statements : "To meet the challenge ", " For my own satisfaction and growth " and " To increase my income ". Conversely, Moroccan entrepreneurs significantly preferred the following $(p<0.001)$ : " To build a business to pass on ", " To build up equity for retirement ", " To gain public recognition ", and "To have fun ». The score difference between the two countries was the highest for this statement, as Mexicans scored 2.77, while Moroccans scored 3.84, a 1.07 mean score difference.

Table 3: Average motivation variables scores by country and total sample

\begin{tabular}{|l|cc|cc|c|c|}
\hline Motivation variables & \multicolumn{2}{|c|}{$\begin{array}{c}\text { Mexico } \\
\text { N=192 Rank }\end{array}$} & \multicolumn{2}{|c|}{$\begin{array}{c}\text { Morocco } \\
\text { N=222 Rank }\end{array}$} & $\begin{array}{c}\text { Score } \\
\text { Difference } \\
\text { (MX-MO) }\end{array}$ & $\begin{array}{c}\text { Total samples } \\
\text { N = 414 }\end{array}$ \\
\hline To meet the challenge $* * *$ & 3.90 & 10 & 3.33 & 17 & 0.57 & 3.60 \\
\hline For my own satisfaction and growth ${ }^{* * *}$ & 4.23 & 02 & 3.69 & 14 & 0.54 & 3.94 \\
\hline To increase my income ${ }^{* *}$ & 4.27 & 01 & 3.73 & 12 & 0.54 & 3.98 \\
\hline To be closer to my family * & 3.74 & 12 & 3.49 & 16 & 0.25 & 3.61 \\
\hline To make my own decisions & 4.02 & 07 & 3.85 & 08 & 0.18 & 3.93 \\
\hline So I will always have job security & 4.02 & 08 & 3.88 & 07 & 0.14 & 3.94 \\
\hline To maximize business growth & 4.09 & 04 & 4.03 & 05 & 0.06 & 4.06 \\
\hline To prove I can succeed & 3.72 & 13 & 3.69 & 13 & 0.03 & 3.70 \\
\hline To create my own job & 4.09 & 05 & 4.06 & 04 & 0.03 & 4.07 \\
\hline To increase sales and profits & 4.20 & 03 & 4.21 & 01 & -0.01 & 4.21 \\
\hline To be my own boss & 4.03 & 06 & 4.09 & 03 & -0.06 & 4.06 \\
\hline To provide jobs for family members & 3.20 & 16 & 3.30 & 18 & -0.10 & 3.25 \\
\hline To maintain my personal freedom & 3.87 & 11 & 4.02 & 06 & -0.15 & 3.95 \\
\hline To acquire a comfortable living & 3.94 & 09 & 4.11 & 02 & -0.17 & 4.03 \\
\hline To build a business to pass on ${ }^{* *}$ & 3.45 & 14 & 3.80 & 10 & -0.35 & 3.64 \\
\hline To build up equity for retirement ${ }^{* * *}$ & 3.37 & 15 & 3.77 & 11 & -0.40 & 3.59 \\
\hline To gain public recognition ${ }^{* * *}$ & 2.92 & 17 & 3.50 & 15 & -0.58 & 3.23 \\
\hline To have fun ${ }^{* * *}$ & 2.77 & 18 & 3.84 & 09 & -1.07 & 3.34 \\
\hline
\end{tabular}

${ }^{*}: p<0.05 ;{ }^{* *}: p<0.01 ;{ }^{* *} p<0.001$ (t-tests of differences between means)

\subsubsection{Factor analysis}

A factor analysis (principal component analysis and orthogonal rotation in varimax mode) of motives was performed in order to determine which motivational factors would appear in each country (table 4). Factors were retained using the Kaiser criterion (eigenvalue $>$ or $=$ to 1 ). The criterion to retain statements was a minimum value of 0.50 for communalities between variables and factorial weights. As a result, the statement "To gain public recognition " was removed from the analysis. Below are the main results provided by table 4:

- The factor analysis yielded five motivation factors: job security related goals (three statements), extrinsic goals (five statements), intrinsic goals (three statements), familyrelated goals (three statements), and goals related to the need for autonomy and 
independence (three statements).

- The proportion of explained variance of $60.8 \%$ is similar to a previous result of $59.6 \%$ by Robichaud et al. (2001) and a proportion of $60.0 \%$ by Kuratko et al. (1997).

- The internal consistency of the four scales, as measured by Cronbach's alpha varied from 0.67 to 0.74 , which signals a strong internal consistency, given the number of statements within each scale. In that respect, Nunnaly and Bernstein (1994) mentioned that, for an instrument including small scales with three to four statements, an alpha coefficient near 0.70 is satisfactory, confirming that statements measure the same construct.

Table 4: Motivation factors resulting from the factor analysis

\begin{tabular}{|l|c|l|l|l|l|}
\hline \multirow{2}{*}{$\begin{array}{l}\text { Factor Components } \\
\text { (Motivation variables) }\end{array}$} & \multicolumn{5}{|c|}{ Factors } \\
\cline { 2 - 6 } & $\begin{array}{c}\text { Job } \\
\text { Security }\end{array}$ & $\begin{array}{c}\text { Extrinsic } \\
\text { Motives }\end{array}$ & $\begin{array}{l}\text { Intrinsic } \\
\text { Motives }\end{array}$ & Family & Autonomy and Independence \\
\hline To be my own boss & 0.760 & & & & \\
\hline To create my own job & 0.693 & & & & \\
\hline So I will always have job security & 0.503 & & & & \\
\hline To maximize business growth & & 0.692 & & & \\
\hline To increase sales and profits & & 0.676 & & & \\
\hline To build up equity for retirement & & 0.665 & & & \\
\hline To acquire a comfortable living & & 0.622 & & & \\
\hline To increase my income & & 0.504 & & & \\
\hline To meet the challenge & & & 0.834 & & \\
\hline To prove I can succeed & & & 0.747 & & \\
\hline For my own satisfaction and growth & & & 0.544 & & \\
\hline To provide jobs for family members & & & & 0.813 & \\
\hline To build a business to pass on & & & & 0.715 & \\
\hline To be closer to my family & & & & 0.603 & \\
\hline To have fun & & & & & \\
\hline To maintain my personal freedom & & & & & 0.715 \\
\hline To make my own decisions & & & & & 0.590 \\
\hline Eigenvalue & 2.318 & 2.271 & 2.039 & 2.027 & \\
\hline Percentage of explained variance & 13.63 & 13.36 & 11.99 & 11.92 & 1.690 \\
\hline Cronbach alpha & 0.68 & 0.74 & 0.66 & 0.67 & 9.942 \\
\hline
\end{tabular}

Principal component analysis condenses sets of variables into a few general dimensions or factors, which allow for the depiction of a global view. Eigenvalues obtained for each factor provide a measure of their importance in explaining the variance associated to these variables. Table 4 shows that the "Job Security " factor explains the highest proportion of the total variance (13.63\%), followed by the " Extrinsic motives » factor with $13.36 \%$ and by the " Intrinsic motives ", " Family " and " Autonomy and Independence » factors with respectively $11.99 \%, 11.92 \%$, and $9.94 \%$. It is however important to understand that factorial analysis does not tell us which factors are most important in the respondents' minds. For example, while the "Family » factor ranked in fourth place in terms of explained variance with $11.92 \%$ (table 4), table 5 shows that it ranks in fifth place in terms of total sample means (3.50 rating). " Job Security " ranked as the primary factor among all respondents with an average rating of 4.02, followed by the " Extrinsic motives " factor at 3.98 and by the "Intrinsic motives " (3.75), "Autonomy and Independence " (3.74) and " Family » (3.50) factors.

Comparisons of cumulative mean scores by motivation factors by country (table 5 ) yielded no significant score differences between Mexico and Morocco for " Job Security " (4.04 and 3.96), " Extrinsic Motives " (3.97 and 3.98) and "Family " (3.47 and 3.53). Both " Job Security " and " Extrinsic Motives " factors were the highest ranking choices in both countries, while the "Family " factor ranked last in Morocco and fourth in Mexico. Mexican entrepreneurs rated the "Intrinsic Motives » factor significantly $(p<0.001)$ higher $(3.95)$ than their Moroccan counterparts (3.56); conversely, Moroccans rated the "Autonomy and Independence » factor significantly $(p<0.001)$ 
higher (3.93) than their Mexican counterparts (3.32).

Table 5: Cumulative mean scores by motivation factors by country

\begin{tabular}{|l|c|c|c|c|c|}
\hline Factors & $\begin{array}{c}\text { Mean } \\
\text { Mexico }\end{array}$ & $\begin{array}{c}\text { Standard } \\
\text { deviation }\end{array}$ & $\begin{array}{c}\text { Mean } \\
\text { Morocco }\end{array}$ & $\begin{array}{c}\text { Standard } \\
\text { deviation }\end{array}$ & $\begin{array}{c}\text { Total sample } \\
\text { mean }\end{array}$ \\
\hline Job security & 4.04 & .81159 & 3.96 & .66668 & 4.02 \\
\hline Extrinsic motives & 3.97 & .75233 & 3.98 & .62904 & 3.98 \\
\hline Intrinsic motives & 3.95 & .78078 & 3.56 & .76069 & 3.75 \\
\hline Autonomy and Independence ${ }^{\star * *}$ & 3.32 & 1.02674 & 3.93 & .81922 & 3.74 \\
\hline Family & 3.47 & .90851 & 3.53 & .86641 & 3.50 \\
\hline
\end{tabular}

***: $p<0.001$

Mean motivation factor scores were computed by calculating the mean scores for all variables composing each factor. For example, the resulting mean factor score for "Extrinsic motives » equals the mean of all five scores corresponding to the five variables forming this factor (table 4).

\section{Discussion and Conclusion}

\subsection{Discussion}

This research aimed at identifying entrepreneurial motives among samples of Mexican and Moroccan entrepreneurs, in order to find similarities and differences. Of interest was also whether factor analyses would yield similar variable groupings as per previous research.

There were more similarities than differences among both samples' profiles. Statistically significant differences were present for the following variables: entrepreneur's age, education, spousal contribution to the firm, management experience, spousal contribution to family income, and debt level. Moroccan respondents were older than their Mexican counterparts, were more educated, and had more management experience. They had more debt and less spousal financial support than Mexicans. There was no significant difference for other descriptive variables, i.e. startup conditions, business success, industry, size (number of employees), hours worked, number of owners, experience in the field, and proportion of necessity startups.

Results also revealed that entrepreneurs from both countries were mostly motivated by extrinsic goals, as their first three choices were: "To increase sales and profits ", "To create my own job » and "To maximize business growth ». The first intrinsic goal selected was " To be my own boss ", which arrived equally in third rank with " To maximize business growth ". An examination in more details of motivations by country, similar results are observed, given that four of the first six goals chosen by entrepreneurs from both countries were Extrinsic. Also, in both countries the first choice was extrinsic, i.e. for Morocco "To increase sales and profits» and, for Mexico, "To increase my income ". This is consistent with the fact that, in both countries, at least half of the respondents had started their business out of necessity $(50 \%$ in Mexico, and $56 \%$ in Morocco).

The results from the factor analysis yielded groupings slightly different from previous findings. While previous research by Robichaud et al. (2001), Kuratko et al. (1997) and Robichaud, et al. (2010) found four factors corresponding to Extrinsic motives, Intrinsic motives, Family, and Autonomy and Independence, in the present study, a fifth factor came in addition to those previous groupings. Labeled as " Job Security ", this new factor includes three motivation variables : "To be my own boss ", " To create my own job » and "So I will always have job security ". In previous studies, these variables were grouped within the "Autonomy and Independence " factor. In terms of its contents, the "Job Security " factor found here is more related to job security than to long term financial security (for retirement) provided by the business in the long term. This factor was equally highly rated by both Mexican and Moroccan entrepreneurs, with cumulative mean scores ranking it first in Mexico and second in Morocco (table 5). Both " Job Security " and " Extrinsic Motives » factors were rated a similar levels with no significant differences. 
Cumulative mean scores comparisons by motivation factors by country reveal virtually no score differences between the three preferred choices in each country. For Mexico, the "Job Security ", " Extrinsic motives " and "Intrinsic motives " factor scores are almost equal, with a 0.09 difference between first and third choice (means of 4.04 and 3.95). For Morocco, the score difference between the first three factors " Job Security ", "Extrinsic motives " and " Autonomy and Independence " is only 0.05 (3.98 and 3.93). There were also no significant differences between the two countries score ratings for the "Family " factor. Therefore, three factors were rated at similar levels : " Job Security », " Extrinsic Motives » and " Family ».

While in both countries male entrepreneurs from Mexico and Morocco put a priority on economic goal factors, it is interesting to find that, on one side, Mexican entrepreneurs rated the " Intrinsic Motives » factor as highly as the economic factors « Job Security » and " Extrinsic Motives "; on the other side, Moroccan entrepreneurs had highly rated the " Autonomy and Independence " factor next to the same economic factors. The level of significance of the difference between Mexico and Morocco for both factors "Intrinsic motives " and " Autonomy and Independence » is $p$ $<0.001$. This result demonstrates that, for Mexican respondents, intrinsic goals were as important for them as monetary goals, whereas intrinsic motives were substantially less important to Moroccan respondents.

In order to explore this finding in more depth, a test of differences between means was performed for the "Intrinsic Motives » factor between respondents with 5 or less employees and those with 6 or more employees. This test revealed that Mexican owners of larger firms had a significantly higher propension to pursue intrinsic goals than their counterparts owning smaller firms (means of 3.87 and 4.12 , significant at $p<0.05$ ). The same analysis performed among the same groups of Moroccan respondents was not significant (means $=3.59$ for the group with 5 employees or less, as compared to 3.48 for the group with 6 or more employees).

\subsection{Conclusion}

In conclusion, the results obtained here have shown that entrepreneurs from Mexico and Morocco harbor predominantly Extrinsic Motives, as well as job security-related goals. Such priorities have been previously observed in Venezuela, Turkey, Romania, as well as sub-Saharan countries (Ghana, Kenya, Nigeria). In general, the predominance of entrepreneurial financial goals has been observed within emerging economies, by opposition to countries where economic conditions are more favorable such as Europe, Canada and the United States. In these latter economies, Intrinsic Motives are prevalent among entrepreneurs, while necessity entrepreneurship remains low (Benzing et al. 2009; Benzing et Chu, 2009). It is, however, notable that Mexican entrepreneurs, coming from two of the most economically active regions in the country, expressed also strong Intrinsic Motives, by opposition to Moroccan entrepreneurs, who were more driven by Independence Motives in addition to Extrinsic Motives.

Major differences between Mexico and Morocco seemed to reside in social aspects focussed on spousal roles as well as the ability for women to start and operate businesses. In parallel, government's implication in fostering entrepreneurship in general, as well as female entrepreneurship in particular appears to be much more developed in Mexico as compared to Morocco.

\subsection{Limits of this research}

This research presented limits on two aspects: 1) The questionnaire being used could have omitted other relevant variables; and 2) The regions studied biased results. In the latter case, samples came exclusively from urban settings, which precludes any generalization of results to total populations (lack of external validity). Nevertheless, knowing that Mexican and Moroccan entrepreneurs primarily pursue extrinsic goals should help local governments in Monterrey and Guadalajara in Mexico, and Fès in Morocco to implement policies better suited to current and future entrepreneurs. 


\subsection{Implications for further research}

Further research could compare entrepreneurial barriers both during startup and under ongoing operations, as well as success factors that are determinant in a firm's survival and growth in both countries. A better understanding of these issues would help governments in defining support programs better suited to entrepreneurs' needs.

Further research focussing on respective gender roles and family structures could shed more light on how an entrepreneurial family functions in each country and which social opportunities and constraints are at play.

\section{References}

African Development Bank/Banque africaine de développement/Centre de développement de l'OCDE (2009). Perspectives économiques en Afrique.

African Development Bank/Banque africaine de développement/Centre de développement de l'OCDE (2015). Perspectives économiques en Afrique.

Allen, H.C. (1967). Les États-Unis - Histoire - Politique - Économie. Verviers: Marabout Université.

Aronoff, C.E. and Ward, J.L. (1995). Family owned businesses: A thing of the past or a model for the future? Family Business Review, 8(2), 121-130.

Aspaas, H.R. (2004). Minority women's microenterprises in rural area of the United States of America : African American, Hispanic American and Native American case studies. GeoJournal, 61(3), 281-289.

Assaidi, A, G Kizaba et N Guilluy-Sulikashvili (2015). Générations Baby-Boomers X et Y: Les barrières entrepreneuriales des entrepreneurs dans le Nord de la France. Gestion 2000, 4(32), 83-106.

Baschiera, A. (2018) Essence of Enterprise 2018. HSBC Private Banking. Accessed July 26, 2018. https://www.hsbcprivatebank.com/en/discover/our-insights/essence-of-enterprise

Bayt.com (2014). Millenials in the Middle east and North Africa Survey. Accessed August 13, 2018. https://img0bm.b8cdn.com/images/uploads/article docs/millenials-survey-report 19564_EN.pdf

Benzing, C., and Chu. H.M. (2009). A Comparison of the Motivations of Small Business Owners in Africa, Journal of Small Business and Enterprise Development 16(1), 60-77.

Benzing, C., H.M. Chu, and Kara O. (2009), Entrepreneurs in Turkey: A Factor Analysis of Motivations, Success Factors, and Problems, Journal of Small Business Management, 47(1), 58-91.

Bewayo, E. (1995). Uganda entrepreneurs: why are they in business? Journal of Small Business Strategy, 6 , 67-78.

Biygautane, M. (2015). Institutional Characteristics of the Gulf Cooperation Council States on Entrepreneurship: Opportunities and Challenges in H. R. Kaufmann et al. (eds.), Entrepreneurial Challenges in the 21st Century. MacMillan, 222-234.

Blawatt, K. (1995). Defining the entrepreneur a conceptual model of entrepreneurship», CCSBE-CCPME Proceedings, 13-37.

Bosma, N., Jones, K., Autio, E. and Levie, J. (2007). Global Entrepreneurship Monitor.

Buresi, P. (2008) L'Empire almohade, le Maghreb et al-Andalus (1130-1269), in F. Hurlet (éd.), Les Empires. Antiquité et Moyen Âge. Analyse comparée, Rennes, PUR, 221-237

Cachon, J.-C., Barragan Codina, J.M., Eccius-Wellmann, C., McGraw, E., and D. A. Myers. (2013). Entrepreneurial Motives and Performance: Evidence from North America, Journal of Management Policy and Practice, 14(5), 50-77.

Carsrud, A. and Brannback, M. (2011). Entrepreneurial motivations: What do we still need to know? Journal of Small Business Management, 49(1), 9-26.

Chedli, M.K.E. (2016). Entrepreneurial Motivation and Performance of Enterprises, Economics, Management and Financial Markets, 11(1), 175-188.

CIA World Factbook Accessed June 2, 2018. https://www.cia.gov/library/publications/theworldfactbook/rankorder/2001 rank.html?countryname=Mexico\&countrycode=mx\&regionCode=noa\&rank= $12 \# \mathrm{mx}$

Cohen, M.D., and Bacdayan, P. (1994). Organizational routines are stored as procedural memory: evidence from a laboratory study. Organ Sci 5, 554-568.

Cromie, S. (2000). Assessing entrepreneurial inclinations: some approaches and empirical evidence. Eur $J$ Work Organ Psychol 9, 7-30

Esfahani, H.S., and Bahramitash, R. (2015). Promoting North African Women's Employment Through SMEs. African Development Bank: Working Paper - North Africa Policy Series.

EY (2013). The Power of Three: The EY G20 Entrepreneurship Barometer 2013: Mexico. 
Fairlie, R.W. and Meyer, B.D. (1991). Ethnic and racial self-employment differences and possible explanations. The Journal of Human Resources, 31(4), 757-793

Fairlie, R.W. (1996). Ethnic and Racial Entrepreneurship: A Study of Historical and Contemporary Differences. New York: Garland Publishing.

Fatoki, O. (2014). Factors Motivating Young South African Women to Become Entrepreneurs. Mediterranean Journal of Social Sciences, 5(16), 184-190.

Feldman, H.D., Koberg, C.S. and Dean, T.J. (1991). Minority small business owners and their paths to ownership. Journal of Small Business Management, 29(44), 12-27

GEM (2016). Rapport National Global Entrepreneurship Monitor, La dynamique entrepreneuriale au Maroc 2016, El Ouazzani, K.

GEM (2017). Rapport National Global Entrepreneurship Monitor, La dynamique entrepreneuriale au Maroc 2017, El Ouazzani, K.

GIH: Global Investment House (2008). Private equity in the MENA region. Retrieved from http://www.startuparabia.com/2008/11/ report-private-equity-in-the-mena-region-october-2008.

Gray, R.K., Foster, H. and Howard, M. (2006), Motivation of Moroccans to be entrepreneurs, Journal of Developmental Entrepreneurship, 11(4), 297-318.

Haddad, E.A. (2017). Linkages and Interdependence in Moroccan Regions. Rabat: OCP Policy Center Brief PB $17 / 37$.

Haddad, E. A., and El-Hattab, F. Ait-Ali, A. (2017). A Practitioner's Guide for Building the Interregional InputOutput System for Morocco, 2013, OCP Policy Center, mimeo.

Hassan, F, A Ramli and NM Desa (2014). Female entrepreneurs in Malaysia: What Drives their Success? International Journal of Business and Management, 9(4), 10-21.

HCP Haut-Commissariat au Plan, Direction Régionale Fès-Meknès. (2016). Annuaire Statistique Régional FèsMeknès. 165 p. Accessed June 20, 2018. https://www.hcp.ma/region-fes/attachment/825784/

Herron, L. and Robinson, R.B. (1993). A structural model of the effects of entrepreneurial characteristics on venture performance, Journal of Business Venturing, 8(3). 281-294.

Hussmanns, R. (2004): Defining and measuring informal employment. International Labour Office, Geneva. 21 p. Accessed July 16, 2018. https://pdfs.semanticscholar.org/14ba/9f7951a6ef3be56b2fdf39953ecf5989f085.pdf

IIEG (Informacion Estadistica y Geografica del Estado de Jalisco). (2017). Poblacion del Area Metropolitana Guadalajara 1990 - 2017. http://iieg.gob.mx/strategos/alcanza-area-metropolitana-de-guadalajara-los-5millones-de-habitantes/area-metropolitana-guadalajara-poblacion-2017-p-2/

INEGI, Instituto Nacional de Estadística y Geografía (2009). Censos Económicos. México: INEGI.

INEGI, Instituto Nacional de Estadística y Geografía (2011). Censos Económicos 2009: micro, pequeña, mediana y gran empresa,estratificación de establecimientos. México. D. F.

INEGI, Instituto Nacional de Estadística y Geografía. (2014) Minimonografia Nuevo León 2014 - Censos Economicos. Accessed July 21, 2018. http://www.inegi.org.mx/est/contenidos/proyectos/ce/ce2014/doc /minimonografias/mnl_ce2014.pdf

INEGI, Instituto Nacional de Estadística y Geografía. (2014b) Minimonografia Los Municipios mas importantes de Mexico 2014 - Censos Economicos. Accessed July 20, 2018. http://www.inegi.org.mx/est/contenidos/proyectos/ce/ce2014/doc/minimonografias/m_dmmip_ce2014.pdf

INEGI, Instituto Nacional de Estadística y Geografía.( 2016). Anuario estadistico y geographico de Nuevo León 2016. 646 p. Accessed July 22, 2018. http://internet.contenidos.inegi.org.mx/contenidos/Productos /prod_serv/contenidos/espanol/bvinegi/productos/nueva_estruc/anuarios_2016/702825083656.pdf

INEGI, Instituto Nacional de Estadística y Geografía.( 2016b) Estructura Economica de Nuevo León en Sintesis 2016. Accessed July 22, 2018. http://internet.contenidos.inegi.org.mx/contenidos/Productos /prod_serv/contenidos/espanol/bvinegi/productos/nueva_estruc/702825090029.pdf

INEGI, Instituto Nacional de Estadística y Geografía.( 2016c). Demografia de los negocios de las zonas metropolas. Esperanza de vida al nacimiento de los negocios en los principales municipios. Accessed July 20, 2018. http://www.inegi.org.mx/inegi/contenidos/investigacion/experimentales/demog_zm/doc/evnm_zmet.pdf

Informador, E (2015). Jalisco, la región con más empresas El Informador. Accessed August 9, 2018 from: http://www.informador.com.mx/jalisco/2010/182075/6/jalisco-la-region-con-mas-empresas.htm

Kantis, H., Ishida, M., and Komori, M. (2002). Entrepreneurship in emerging economies: the creation and development of new firms in Latin America and East Asia: summary report. Inter-American Development Bank.

Kelley, D., Singer, S. and Herrington. M. (2015/16). GEM Global Report.

Kuratko, D.F., Hornsby, J.S. and Naffziger, D.W. (1997). An Examination of Owner's Goals in Sustaining Entrepreneuriat, Journal of Small Business Management 35(1), 24-33.

Langan-Fox, J and Roth, S. (1995). Achievement motivation and female entrepreneurs. Journal of Occupational and Organizational Psychology, 68, 200-218.

Larsson, M and ER Erlandsson (2013). Female Entrepreneurs in Honduras: The Motivation Factors Behind their Decisions. Jönköping University. 52 p. 
Le Cabellec, O. (2017) Maroc - Les nombreux défis d'un pays en mutation. Perspectives. No 17/044 14 février 2017. Credit Agricole. Accessed July 26, 2018. file:///F:/Recherche/Le\%20Cabellec\%202017\%20Maroc \%20D\%C3\%A9fis\%20d'un\%20pays\%20en\%20mutation.pdf

Lévi-Provençal, É. (éd., trad. et introd.) (1928) Documents inédits d'histoire almohade. Fragments manuscrits du legajo 1919 du fonds arabe de l'Escurial, Paris: Geuthner.

Light, I. (1979). Disadvantaged minorities in self-employment. International Journal of Comparative Sociology, 20(1-2), 31-45.

MENAPEA: MENA Private Equity Association. (2015). 10th Annual MENA Private Equity and Venture Capital Report. http://menapea.com/2015AnnualReport/10th_MENAPEA_AnnualReport_2015_Rev15.pdf.

Méndez, M.J.S. (1998). El neoliberalismo en México ¿éxito o fracaso? Rev. Contaduría y Administración. Universidad Nacional Autónoma de México (UNAM). 191:56-65.

México, Gobierno Federal (2016). Pymes es la bon fundamental para el crecimiento en Mexico. Promexico. Accessed June 22, 2018 from Negocios Internacionales: http://www.promexico.gob.mx/negociosinternacionales/pymes-eslabon-fundamental-para-el-crecimiento-en-mexico.html

Morris, M.H., Miyasaki, N.N., Watters, C.E. and Coombes, S.M. (2006). The Dilemma of Growth: Understanding Venture Size Choices of Women Entrepreneurs, Journal of Small Business Management, 44(2), 221-244.

Mundo Ejecutivo (2015). Jalisco, el estado que nunca pierde. Accessed July 18, 2018 from: http://mundoejecutivo.com.mx/economia-negocios/2015/06/17/jalisco-estado-que-nunca-pierde June 14,2015

Naffziger, D.W., Hornsby, J.S. and Kuratko, D.F. (1994). A Proposed Research Model of Entrepreneurial Motivation, Entrepreneuriat Theory and Practice, Fall, 29-41.

Negrete, R. (2008). Measuring Informal Employment in Mexico. Working Paper. Instituto Nacional de Estadística y Geografía (INEGI). $13 \quad$ p. Accessed July 20, 2018. http://www.wiego.org/sites/default/files/publications/files/Negrete_Informal.Employment.Mexico.pdf

North, C. (2012). Mexico's First Government-Sponsored Seed Fund Debuts. Emprende August 1, 2012. Accessed July 24, 2018. http://www.pvangels.com/news-mexico/2252/mexicos-first-governmentsponsored-seed-fund-debuts

Nuevo León, State of (2013). Perfil Económico de México y Nuevo León. Accessed August 9,2018 from http://sg.nl.gob.mx/DataNL/files\%5CDNL00000800.pdf

Nunnally, J.C. and Bernstein, I.H. (1994). Psychometric Theory. Third Edition. New York: McGraw-Hill.

Pineda, A (2014). El Empresario. Accessed July 29, 2018 on Mujeres, las que más aprovechan créditos en Guadalajara:http://elempresario.mx/actualidad/mujeres-que-mas-aprovechan-creditos-guadalajara 21 mai 2014.

Porter, M., Sachs, J., and McArthur, J. (2002). Executive summary: Competitiveness and stages of economic development. In M. Porter, J. Sachs, P. K. Cornelius, J. W. McArthur, \& K. Schwab (Eds.), The global competitiveness report. New York: Oxford University Press.

Radojevich-Kelley, N. (2014). Mexican Small Business Owners and Entrepreneurs: Who are They, What Motivates Them and What Challenges Do They Face? The Journal of Business Leadership, 194-216.

Robichaud, Y. (2011). Les facteurs explicatifs de la performance des petites entreprises, Saarbrucken, Germany: Editions universitaires européennes, 193p.

Robichaud, Y., Cachon, J.-C. and Haq, R. (2010). Motives, Success Factors, and Barriers Among Canadian Female Entrepreneurs: The Case of Greater Sudbury, Entrepreneurial Practice Review, 1(2), 36-64.

Robichaud, Y., McGraw, E. and Roger, A. (2001). Toward the Development of a Measuring Instrument for Entrepreneurial Motivation. Journal of Developmental Entrepreneurship, 6(2), 189-201.

Saad Alami, Y. (2016). Les nouvelles orientations de Fès-Meknès. L'Économiste. No 4861. Accessed July 29, 2018. http://www.leconomiste.com/article/1002677-les-nouvelles-orientations-de-fes-meknes

Samaniego, N. (1998). Urban Self-Employment in Mexico: Recent Trends and Policies, International Conference on Self-Employment OECD/FCRE/RCIT' Burlington, Ontario, Canada, September 1998.

Sánchez, R.M., Salazar, A.L., Ricardo Contreras Soto, R.C. (2014). . El emprendimiento y crecimiento de las Pymes. Acta Universitaria, 24(NE-1), 59-72. doi: 10.15174/au.2014.701.

Schwab, K. (2016) The Global Competitiveness Report 2016-2017. Geneva: World Economic Forum.

Schwab, K. (2017) The Global Competitiveness Report 2017-2018. Geneva: World Economic Forum.

STPS, Secretaria del Trabajo y Prevensión Social. Laboral, S. d. (2016). Accessed July 17, 2018//www.stps.gob.mx/bp/secciones/conoce/areas_atencion/areas_atencion/web/pdf/perfiles/perfil\%20n acional.pdf

STPS Secretaria del Trabajo y Prevensión Social -INEGI. (2017) Encuesta Nacional de Ocupación y Empleo. Informacion Laboral, Noviembre 2017. Accessed July 31, 2018. http://www.stps.gob.mx/gobmx/estadisticas/pdf/perfiles/perfil\%20nuevo\%20leon.pdf

United Nations (2018). Middle-East - Economic and Social Commission for Western Asia (ESCWA) Accessed July 26, 2018. http://www.un.org/en/sections/where-we-work/middle-east/ 
Villareal, M.A. (2017). Mexico's Free Trade Agreements, Congressional Research Service. 17 p. Accessed August 12, 2018. https://fas.org/sgp/crs/row/R40784.pdf

Webber, J (2015). Guadalajara: Mexico's Second City is a Latin American Silicon Valley. Financial Times, June 16, 2015. Accessed July 25, 2018. http://www.ft.com/int//cms/s/2/ec7461a8-ffb3-11e4-bc3000144feabdc0.html\#axzz3zRrPEz7m

World Economic Forum (2017). The Africa Competitiveness Report.

World Bank (2016). Nouvelles/ Communiqués de presse en date du 2016/10/17. http://www.worldbank.org/en/news/press-release/2016/10/17/european-investment-bank-and-world-bankgroup-partner-to-support-entrepreneurs-in-mena

World Bank (2017). Igniting Climate Entrepreneurship in Morocco: Findings from the Climate Entrepreneurship and Innovation Ecosystem Diagnostic.

Yatribi, T., and Alhadj, S. (2016). L'entrepreneuriat comme orientation de carrière: Le cas des ingénieurs marocains. International Journal of Innovation and Applied Studies, 15(2), 339-351.

Zimmerman, M.A., and Chu, H.M. (2013). Motivation, Success, and Problems of Entrepreneurs in Venezuela, Journal of Management Policy and Practice, 14(2), 76-90. 